\title{
Positive Character Education Values Found in Simba, The Lion King (1994) Movie
}

\author{
Piscayanti, K.S. ${ }^{1}$, Suprianti, G.A.P. ${ }^{2}$, Premana, M.Y.H. ${ }^{3}$
}

1,2,3,4 Universitas Pendidikan Ganesha

A R T I C L E I N F O

Article history:

Received 21 July 2020

Received in revised

Form 01 August 2020

Accepted 18 August

2020

Available online 30

August 2020

characterization, film,

The Lion King, values of

character education
Keywords:

\begin{abstract}
A B S T R A C T
Motion pictures or movie is highly related with someone's daily life that easily to be obtained by almost most of the people. Additionally, movie can deliver ideas, experiences, and ways of thinking through visual and sound which offered by the film that engages spectators' minds and emotions. This study aimed to analyze the values of character education on Simba in The Lion King (1994) movie. This study was a descriptive qualitative study in which textual analysis was used in order to analyse the data where the data in the form of movie was treated like a text and analysed in the cycling process in order to obtain the dependable data. The result of this study showed that The Lion King (1994) contained all values of character education which stated by Ministry of Education and Culture. Those values were showed in different timing where in the beginning of the movie there were 9 characters namely; religious, tolerant, discipline, autonomous, hardworking, cooperative, solidary, responsible, and honest, while in the middle part of the movie there were 11 characters, namely; sincere, nature loving, peace loving, patriotic, creative, resilient, appreciative, integrity, loyal, inclusive, and nationalistic. This result proves that The Lion King
\end{abstract} (1994) movie is a good movie for children which is suitable to be used in learning purposes.

\section{Introduction}

Education quality is a country's investment. As the country's future investment, education has to be started since early stage as a systematic and development program in the form of various kind of programs, such as education in early childhood, in elementary, primary, secondary up to university (Rasyid, 2007; Valor et al., 2020). Education forms an intelligent and a high quality of human resource which became one of the important aspects of development. However, education is not simply transferring knowledge, but education purposes to build a generation who has a good capabilities and abilities in terms of cognitive, affective, and psychomotor aspect (Alfaiz, 2016; Nurpratiriningsih, 2011). It can be said that education cannot be done only concerning in one aspect, this is because there are three important domains that have to be fulfilled. The same as cognitive, and psychomotor, affective who deals with attitude is one of the important parts of education. In order to achieve an optimal result of moral education, there are several aspects which have to be considered, such as; education, material, method, and evaluation (Rukiyati, 2017; Cheung \& Lee, 2010). This statement indicates that there are many aspects which influenced the success of moral education.

There is variant method that can be implemented to learn character education. One of them is using alternative media, such as movie. Audiovisual media such as movie is not only for entertainment purposes, but it is also can be used for educating. Motion pictures or movie is highly related with someone's daily life that easily to be obtained by almost most of the people. Additionally, movie can deliver ideas, experiences, and ways of thinking through visual and sound which offered by the film that engages spectators' minds and emotions (Devi, 2018; Bordwell \& Thompson, 2010).

In reality, movie is very easy to be accessed and there are many kinds of movie which contains different content. Since this current development most people especially children are consuming all kind of contents without considering the effect of the content, such as, violent, pornography, bullying, and inappropriate content. Children tend to have a problem in filtering television program according to their incapability in differentiate good and bad which become the primary problem in Indonesia (Pramadiansyah, 2014; Zhou et al., 2017). This problem can be overcome by choosing the appropriate program that contain good value in order to get the positive value of movie. One of the company which 
produced a good movie is Walt Disney. This research has a new perspective in exploring the character values found in Simba The Lion Kong (1994) movie. It explores the 9-character values in the beginning and 11-character values in the middle which focuses on the character development of Simba.

Walt Disney Company is a company that produces amusing entertainment experiences for the whole family with good quality and storytelling (The Walt Disney, 2004). Walt Disney company has produced many movies and TV shows that become very popular among the people especially children. Movie from Walt Disney often contains many character education values. (Payani, 2018) conducted a research entitled "The Identification of Character Education Values on The Main Character of Zootopia" where the result of the research is there 17-character education values that found in the movie in which only 1 value which is not found in the movie namely religious values. The 17-character education values are; hardworking disciplined, responsible, creative, appreciative, autonomous, peaceful, tolerant, democratic, patriotism, nationalism, honest, bibliophile, environmental awareness, social care, friendly/communicative, and curious. Another search which analysed about movie is a research from (Devi, 2018) entitled "Character Education Values in The Characterization of Brad Cohen in Front of The Class" where the research found that there are 18 character education values, such as; autonomous, social care, honest, hardworking, curious, tolerant, peaceful, communicative, responsible, appreciative, discipline, creative, nationalism, bibliophile, patriotic, democratic, environmental awareness, religious. These findings proved that Disney movie is containing many moral values which is relevant to the purpose of this research.

The present study discusses about character education found in a movie produced by Walt Disney entitled The Lion King (1994). The Lion King movie tells about a young prince named Simba who struggled in finding his place in the great circle of life. The story takes a place in the pride land where Simba as the son of king Mufasa and queen Sarabi has to face his own uncle named Scar with the help of his friends Nala, Timon and Pumba and also his people. He has to face his destiny to be the king and saves his homeland from Scar's evil domination (Hinson, 1994).

This study focuses on Simba as a main character in the movie. The movie is chosen because from the preliminary observation, where The Lion King (1994) movie watched several times then observed. It found that The Lion King (1994) movie is relevant to the purpose of this study. This can be proven by a study from (Ward, 1996) which stated that The Lion King's narrative story contains myth and moral purposes which are inserted in movie. Although the previous study reveals about the moral values in The Lion King movie, but the research does not reveal specifically about character education found in The Lion King (1994). It also can be compared with a study conducted by (Reiner, 2009) who reveals about Simba's leadership behavior in The Lion King (1994), where this present study focuses to find out character education values based on five core values which stated by Ministry of Education and Culture which has not been done in other previous research.

\section{Methods}

This study was descriptive qualitative research. In collecting the data, this study used textual analysis where Lion King (1994) movie as the subject of this study was treated as a text. This study used five core values stated by Ministry of Education and Culture where there were 5 core values, namely; religious, nationalism, autonomous, cooperative, integrity, and there are 15 sub-values, namely; sincere, nature loving, peace loving, tolerant, patriotic, discipline, creative, hardworking, resilient, solidary, inclusive, appreciative, responsible, honest, and loyal another theory which used to interpret the data in this research are narrative and stylistic elements. The subject of this research is a movie entitled The Lion King (1994) movie produced by Walt Disney. The Lion King movie which analysed in this study was in the form of a DVD version released by Walt Disney. This movie is directed by Roger Allers and Rob Minkoff, produced by Don Hahn. It is written by Irene Mecchi, Jonathan Roberts, Linda Woolverton, starred by Matthew Broderick, James Earl Jones, Jeremy Irons, Jonathan Taylor Thomas, Moira Kelly, Nathan Lane, Ernie Sabella, Rowan Atkinson, Robert Guillaume, Madge Sinclair, Whoopi Goldberg, Cheech Marin, Jim Cummings, the music by Hans Zimmer, Mick Glennie-Smith, Mark Mancina, Elton John and Tim Rice. The object of this study is the values of character education in the main character named Simba in The Lion King (1994) movie, where the main character is chosen because based on the theory from (Wilson, 1976) states that major character is a character who plays an important part in the story where most of the story is about the character. In this case, there are a lot of data that can be obtained as Simba is the main character in The Lion King (1994) movie.

The instruments which used in this research were table of sequence that used to do a sequence segmentation, classify the values of character education, and show the decoupage of the sequence, field notes were used in the process of collecting every scenes which contained the values of character 
education of the main character in the film. The techniques of data collection in this study were streaming, note taking, and documenting. Data collection was done through streaming which used to understand the film until it was divided into the beginning, middle, and end part, note taking was used to note every sequence and scene in the movie, classifying was used to classify sequences as well as scenes which contained the values of character education, documenting is used to provide pictures in the form of screenshot of every sequence which contained values of character education, data reduction is the process of adding and eliminating data, data documentation is the process of showing the data in the form of table of sequence and figure which contained values of character education, conclusion drawing is the process of making conclusion of the data. The data analysis was done simultaneously and repeatedly in order to get reliable data of analysis.

Procedure of this study were streaming, note taking, data classification, documentation, and analysis. Streaming process was done by watching the movie several times until getting the data in the form of the values of character education in the main character of Simba. In the streaming process the plot development was obtained such as; beginning part, middle part, and the end part of the movie. Until it was identified, the data in the form of sequence segmentation was noted by doing note taking. The result of note taking process are sequence segmentation, character education values, visual imaginary, dialog, sound, and cinematography aspect which is important in the analysis process. Then in presenting the data, documentation process was conducted in order to get the data in the form of screenshot of every sequence which contained the values of character education. The documentation process was purposed to give meaningful data which was really important to facilitate the reader of the study to get a fully understanding of the data. Finally, Analysis process was done through interpreting the data using sentences in order to make a meaning of the data. The data in the form of sequences which was contained the values of character education and the screenshot of every pictures were interpreted in the form of sentences and paragraphs in order to describe the data and making meaning of it. The last but not least was a conclusion drawing. Through this process conclusion was drawn. The conclusion process can be classified as a valid one when the data which was presented had been analysed through a cycling process, where the data were analysed several times until the conclusion showed a consistent result.

\section{Result and Discussion}

The result of this study are values of character education based on 5 core values which stated by Ministry of Education and Culture. There are 20 values of character education, where the values are divided into 5 core values of character education, namely; religious, nationalist, autonomous, cooperative, integrity, and the sub-values of character education, namely; sincere, nature loving, peace loving, tolerant, patriotic, discipline, creative, hardworking, resilient, solidary, inclusive, appreciative, responsible, honest, and loyal. Those values of character education are presented in table 1.

Table 1. Character Values Found in Simba

\begin{tabular}{|c|c|c|c|c|}
\hline No & Values & Sub Value & Sequence & Frequency \\
\hline \multirow[t]{4}{*}{1.} & Religious & & $13 a, 1 b, 8 a, 10 b$ & 4 \\
\hline & & Sincere & $12 c, 12 h, 9 c, 4 a, 9 a$ & 5 \\
\hline & & Nature loving & $13 a, 11 c, 7 c$ & 3 \\
\hline & & Peace loving & $\begin{array}{l}12 c, 9 b, 13 a, 7 b, 12 d, 7 c, 9 d, 12 f \\
8 a, 9 c, 12 a\end{array}$ & 11 \\
\hline \multirow[t]{4}{*}{2.} & Nationalistic & & $12 \mathrm{c}, 9 \mathrm{~d}, 11 \mathrm{c}, 10 \mathrm{e}$ & 4 \\
\hline & & Tolerant & $3 b, 7 b, 7 c, 9 b, 13 a, 9 c, 8 a$ & 7 \\
\hline & & Patriotic & $3 d, 9 a, 12 c, 3 f, 12 b, 12 d, 11 c$ & 7 \\
\hline & & Discipline & $2 a, 13 a$ & 2 \\
\hline \multirow[t]{4}{*}{3.} & Autonomous & & $11 b, 11 c, 3 a, 12 c, 12 f$ & 5 \\
\hline & & Creative & $12 \mathrm{a}, 7 \mathrm{c}$ & 2 \\
\hline & & Hardworking & $\begin{array}{l}12 \mathrm{c}, 2 \mathrm{~d}, 5 \mathrm{c}, 12 \mathrm{f}, 12 \mathrm{a}, 12 \mathrm{~d}, 2 \mathrm{a}, 2 \mathrm{~b}, \\
2 \mathrm{c}, 3 \mathrm{~b},\end{array}$ & 10 \\
\hline & & Resilient & $7 b, 12 c, 4 a, 5 b, 10 e, 7 c, 3 d$ & 7 \\
\hline \multirow[t]{2}{*}{4.} & Cooperative & & $\begin{array}{l}3 a, 9 a, 7 c, 2 d, 3 b, 11 c, 12 b, 12 d, \\
12 h, 5 b, 8 a, 9 b, 12 a, 13 a, 3 c, 2 e, \\
3 d, 4 a\end{array}$ & 18 \\
\hline & & Solidary & $\begin{array}{l}\text { 7b, 3b, 12d, 8a, 3a, 3c, 12c, 7a, } \\
7 c, 11 c\end{array}$ & 10 \\
\hline
\end{tabular}




\begin{tabular}{|c|c|c|c|c|}
\hline No & Values & Sub Value & Sequence & Frequency \\
\hline \multirow{6}{*}{5.} & \multirow{6}{*}{ Integrity } & Inclusive & $11 \mathrm{c}, 12 \mathrm{f}$ & 2 \\
\hline & & Appreciative & $7 c, 12 \mathrm{~h}, 7 \mathrm{a}, 8 \mathrm{a}, 11 \mathrm{c}$ & 5 \\
\hline & & & $12 c, 12 d, 13 a, 3 c$ & 4 \\
\hline & & Responsible & $\begin{array}{l}12 \mathrm{e}, 12 \mathrm{c}, 12 \mathrm{~b}, 13 \mathrm{a}, 11 \mathrm{c}, 12 \mathrm{f}, 2 \mathrm{a}, \\
2 \mathrm{~b}, 2 \mathrm{c}, 3 \mathrm{~d}, 3 \mathrm{e}\end{array}$ & 10 \\
\hline & & Honest & $12 c, 5 c, 7 b, 8 a, 10 c, 2 a, 2 e, 3 d$ & 8 \\
\hline & & Loyal & $11 c, 9 a, 3 c$ & 3 \\
\hline \multicolumn{2}{|c|}{ Total } & & & \\
\hline
\end{tabular}

Based on the table Character above, it can be seen that the values of character education which are appeared in Simba's characterization are religious, sincere, nature loving, peace loving, nationalistic, tolerant, patriotic, discipline, autonomous, creative, hardworking, resilient, cooperative, solidary, inclusive, appreciative, integrity, responsible, honest, and loyal. The description of those characters are presented below.

Cooperative is working together in solving a problem which achieved through helping each other's, making good communication and relation with others, etc (Lin et al., 2010). Simba shows his cooperative character 18 times in the movie since the early part until the end of the movie, which makes cooperative character becoming the highest frequency of character which owned by Simba. Simba's cooperative character is in the form of making a good communication with his family and friends. It shows when Simba warmly greets his uncle Scar after his lesson with his father Mufasa. Although Scar is described as an evil character in the film, but Simba still shows his friendliness with his uncle by greeting him nicely. Moreover, Simba shows his cooperative attitude when he cooperates with his friend Nala in order to accomplish their secret mission to go to elephant graveyard.

Peace loving is attitude which made other people feel comfortable through his/her present (A'yunin et al., 2019). Peace loving character appears 11 times in the movie. The movie shows Simba as a peace-loving character when he meets with Timon and Pumba in the middle part of the movie until the end part of the movie. It can be said that Simba is starting to develop his peace-loving character as he grows up with Timon and Pumba. Until the end part of the movie, Simba still maintains his peace-loving character when he decides to not kill his uncle and let his uncle to leave the pride rock safely in order to avoid meaningless riot between Scar's army and his people. It can be seen that Simba's peace loving character is developed in the middle of the film where the movie shows the young prince Simba as a child who like to explore and learns about new things which lead Simba is less peace loving in the beginning of the movie, but it develops in the middle as Simba grows up and it is maintained well until the end of the movie.

Hardworking is putting intense effort in order to do a job properly (Fatah, 2018). Hardworking character shows 10 times from the beginning of the movie until the end of the movie. It shows that Simba develops his hardworking character well and maintains it until the end of the movie. The movie several times shows Simba as a hardworking character, where Simba as a student which is seriously and eagerly like to learn from his father, even in the beginning part of the movie Simba is shown waking up really early and he is shown intensively trying to wake Mufasa in order to teach him a lesson as soon as possible. Moreover, Simba hardworking character is shown when he intensively practices his roar with a chameleon. It happens when Scar mocks Simba that he has a very little roar, then Simba decides to do a practice by own in order to improve his roar over and over until he manages to produce a better roar. Finally, in the end part, the movie consistently shows Simba as a hardworking character when he seriously fights his evil uncle as his last effort to save his homeland from Scar's evil domination. In the fight, Simba shows his best effort in order to defeat Scar, he tries many moves and at first Scar is shown as if he dominates the fight because he uses a dirty trick where he throw a dirt to Simba's eyes, but Simba manages to find a way to beat his evil uncle and he finally fulfils his mission in saving his kingdom.

Responsible is having a commitment in every act and work work (A'yunin et al., 2019). Responsible character appears 10 times in the film. It shows from the beginning and the end of the movie, but Simba does not develop this character well because in the middle part of the film he does not show his responsibility due to his new lifestyle when he meets with Timon and Pumba. Simba's responsible character is in the form of his commitment in doing every lesson that is given by Mufasa as his tutor. Then, as a young prince Simba is shown as a character that responsible enough in doing his duty which is learnt about his kingdom and his responsibility as a future king from his father Mufasa. Further, Simba as a leader of a team can be said as a responsible leader as he fulfils his promise to Nala that he will show an amazing place when Nala agrees to do an exploration with him. Finally, at the end of the movie Simba's 
decision to go back to pride rock shows Simba as a responsible character when he has to face his destiny to become a king of pride rock.

Solidary is a support that acquired from sharing the same emotion and goal which usually shared by an individual or a group of people (Hornby, 2005). Solidary character shows 10 times in the movie. It is developed well by Simba because Simba consistently shows this character from the beginning until the end of the movie. For example, when Simba and Nala give their big smile and beg for a permission to Simba's mother in order to permit them to go to an exploration. Their act is a kind of a result from having the same motive in which they really want to do an exploration and they need a permission from Sarabi. Further, Simba shows his solidary character when he easily comes along with Timon and Pumba when they share the same problem then find out that they have the same past mistake. At the end of the movie, Simba's solidary character is reflected when all lioness and pride rock's people start to save Simba when they know that they have the same enemy which is the Scar who kills their precious king Mufasa in the past.

Honest is always telling the truth and can be trusted in terms of words, act, and work (A'yunin et al., 2019). Simba's honest character shows 8 times during the movie. It can be seen that Simba develops his honest character well because it constantly appears from the early development until the end development of the movie. At the beginning of the film, Simba shows his honest attitude when he tells a fact about Mufasa's promise where Simba's sentence in one of the beginning scenes infers that Mufasa has a promise to him to teach him a lesson tomorrow morning. Then, in order to remind his father that he has a promise, he wakes his father up and mentioning about the fact about Mufasa's promise. Then, Simba's as an honest character is shown again when he reveals about his problem to Timon and Pumba which leads Timon and Pumba starts to trust and acknowledge him as their buddy. Eventually, at the end part Simba develops his honest character when he tells about the truth of his own mistake which causes Mufasa's death to his people. This honest act becomes the bravest honest action which done by Simba where he has to admit his worst mistake which becomes one of the reasons of Mufasa's death.

Tolerant is attitude which accept and appreciate others' people, religion, ethnic, opinion, and behaviour (Saputra, 2020). It appears 7 times in the movie and it often appears since the early part until the end part of the movie. Simba is shown as a tolerant character in the beginning of the film when he makes a friend with many kinds of animal such as rhino, hypo, monkey, elephant, etc. It shows that Simba as a prince of pride rock does not differentiate the others although they have different appearance and race. It shows again when Simba tastes a food from Timon and Pumba's home in the middle part of the movie. Although Simba thinks it is gross at first, but he manages to try the food in order to appreciate Timon and Pumba's offers. Then, finally he likes the food because the food is not as bad as its look. In the end part of the movie Simba still maintains the tolerant character when he is shown stood in a giant stone of the pride rock's throne accompanied by Timon, Pumba, Rafiki, Nala and a cub which is his son in the presentation ceremony.

Patriotic is a willingness to make a sacrifice without considering any consequence in order help other people, citizen, and the nation (Azizah, 2013). It appears 7 times in the movie. It appears during the middle part and the end part of the movie. It can be said that Simba starts to develop this character in the middle part of the film when he explores outside his kingdom and he succeed to maintain it until the end part of the film when he faces Scar. His patriotic character is in the form of his action of saving Nala's life from hyenas' attack where he sacrifices his self in order to save his friend. Simba also saves Pumba's life when he is chased by a hungry lioness who wants to eat him. Another example is Simba's heroic action of saving Sarabi from Scar's abuse by confronting Scar in the name of his mother.

Resilient is the ability to recover as soon as possible from a difficult time (Hornby, 2005). Simba's resilient character is shown 7 times in the movie. He starts to develop the character in the middle of the movie until the end of the movie. It can be said that the character starts to appear when the conflict starting to arise during the plot development. The example of Simba's resilient character is when Simba manages to cure his insecure feeling as soon as Mufasa lectures him about the meaning of being brave. Simba also manages to cure himself from his guilty feeling when he meets with new friends such as; Timon and Pumba which teach him about "Hakuna Matata" which the motto that enable him to forget his guilty feeling for a while, until he finally meet with Rafiki his father's old friend that leads him to forgive himself and allowing him to choose the right decision which is confronting his problem and learn from it instead of run from his problem. Another example is when Scar mentions about Simba's past mistake and tries to make Simba feels down. Simba manages to overcome it because he states that he already forgives himself from his past mistake even before Scar mentions it.

Sincere is feeling, beliefs, or behavior which refers to a person that expressing what he really feels and thinks (Hornby, 2005). The movie shows Simba as a sincere character 5 times in a different scene. It can be seen that Simba's honest feeling appears consistently since the beginning until the end part of the 
movie, where Simba's sincere character is in the form of his true feeling when he explains that he wants to be brave as Mufasa. Then, in the end of the film Simba shows his sincere when he meets with his old friend Nala. Simba is really happy when he accidently meets with Nala. Simba's sincere character is in the form of his true feeling that he misses Nala so much after a long time he leaves the pride rock. Another example of Simba's sincere character is when Simba claims his throne after a long fight with Scar and his army. In the movie, he butts his head to Sarabi and Nala then he holds Rafiki with a sincere smile with reflected his grateful that they finally win the war and reclaim the pride rock's throne.

Autonomous is attitude which is not depending on other people that indicates by always put an effort on achieving something, such as dream (Derlina \& Sabani, 2014). This character appears 5 times during the movie. The movie often shows Simba as a character which is independent enough where the movie frequently shows Simba walk, learn, and do his job by himself. It indicates that Simba is a character that not cling to the others. Even though Simba is shown as an independent character but several times in the movie Simba is shown do his work with his friends but in this case, it can be seen Simba's role is still dominant which shown him as a dependable leader in that group. There are several example of Simba's autonomous characters, as follows; Simba autonomous character is in the form of Simba's act when he prefers to tidy his mane by himself than accepts Sarabi's help. Then, Simba's autonomous character is shown when he decides to go back to pride rock alone. His autonomous character is in the form of his action where he runs alone to the pride rock because he does not want to involve his friend with his personal responsibility.

Appreciative is an act of respect and appreciating every achievement of other people and always try to be an useful person for the society (Derlina \& Sabani, 2014). This character is shown 5 times in the movie. In the beginning Simba does not show a significant attitude which indicates appreciative character, but in the middle until the end Simba develops this character and maintain it. It appears when Timon and Pumba saves Simba who passes out in the dessert. Then, Timon states that he helps Simba as soon as Simba awake. Simba's appreciative character was shown when he appreciated Timon's help through his word when he compliments Timon for his great help. Another example is during Simba's son ceremony where he appreciates his people because of their great help in ending Scar's domination.

Religious is having faith to the god which realized by several kind of ways, for examples; always do the religion beliefs, appreciate the difference in other religion, tolerant to other people who have different beliefs, and live in peace with followers of other religion (Saputra, 2020). The movie shows Simba is having religious character since the beginning of the movie until the end. It appears 4 times, where it shows when Rafiki blesses Simba in a presentation ceremony in which he blesses Simba with a water in front of Simba's parent and shows him to the pride rock's citizen and rises him to the sky which has a similarity with a Christian's ceremony of baptism. The ceremony indicates that the pride rock's people has a belief and obeys the belief as they do the ceremony. At the end of the movie, it shows that Simba does the same ceremony when he has a son with Nala. This indicates that Simba maintains his religious character until the end and inherits this character to his generation.

Integrity is an attitude which showed an effort to have a commitment and loyalty in humanity values, always be believed in terms of words, act, and work (Derlina \& Sabani, 2014). This character is shown 4 times in the movie. In the early part of the movie Simba does not show integrity character. He starts to have this character in the middle part of the movie until the end of the movie. His integrity character is shown through his word to Nala which proves Simba as a character that can be believed in term of word, where he promises to Nala about an amazing place named elephant graveyard. Then, when they finally arrive to the place Nala really likes the place as Simba's promise. Then, the movie also proves Simba as an integrity character when Nala recognizes Simba as the one who deserves to be a pride rock's king who recognize by all his people as the one who has a great sense of responsibility to be a true king.

Nationalistic is an act, behaviour that always respecting and showing appreciation to the country in which it related with putting nation's importance at the first place (Danang \& Marzuki, 2016). This character shows 4 times during the film. Simba starts to develop this character in the middle of the film until the end of the film. In the film Simba is shown as a character that really cares about his country's condition. He is shown as a nationalistic character through his shock reaction knowing about a disaster in pride rock. Then, he decides to go back to his country in order to save his country from Scar's evil domination and returns a happiness to his country.

Nature loving is an effort to prevent disaster and maintain the nature and (A'yunin et al., 2019). It shows 3 times in the film. Simba shows his appreciation attitude to the nature when he is away from pride rock in the middle part of the movie until the end part of the movie. When he enters a jungle where Timon and Pumba live Simba amazes with the jungle's view and he states that the jungle is beautiful. Another example which proves Simba as a character that nurtures the nature well is when pride rock is destructed by Scar. After Scar leads the pride rock, pride rock shows as a barren place, then when Simba defeats Scar 
and claims the throne pride rock shows as a green land and a good place where all animals can live happily in that place.

Loyal is having faithful and supportive attitude to someone or something (Hornby, 2005). This character shows 3 times in the movie. Simba starts to develop this character in the middle and in the end of the movie which indicates Simba's loyal character is developed well during the film. There are several scenes which show Simba as a loyal character, as follows; at the beginning, he shows his loyalty to Nala through his action of saving her from dangerous circumstance where he returns to save Nala when he knows that Nala is almost caught by the hyenas. Then, in the middle Simba proves his loyalty to his friend Timon and Pumba when he saves Pumba and Timon's life from lioness attack. Finally, in the end of the movie Simba still shows his loyalty to his country when he decides to save his country although he has away from pride rock after a long time.

Discipline is an act which show obedience in terms of every policy and rules (A'yunin et al., 2019). The character is shown 2 times in the film. This character appears since the beginning of the movie, but it does not appear in the middle part of the movie. Then, in the end part of the movie Simba stars to develop this character again. It can be said that Simba already has discipline character but he does not develop this character well due to a conflict which related with Mufasa's death, where he has to leave pride rock and lives a non-responsible life with Timon and Pumba as an outcast. Simba's discipline character firstly appears when he wakes up early in the morning in order to get a lesson as soon as possible from Mufasa. Then, in the end of the movie Simba's discipline character appears in the form of his obedient attitude in attending a royal ceremony presentation of his son as pride rock's new prince.

Creative is an ability to create a new things which is different with the old one (Kim et al., 2020). This character appears 3 times in the movie. Simba starts to develop this character in the middle part of the movie and he maintains this character until the end of the movie. He shows creative character when Timon shows a jumping trick to Pumba and Simba. Pumba imitates Timon's trick where he jumps exactly the as Timon, but when it comes to Simba's turn. He creates a new trick of jumping which is different with Timon and Pumba's trick. Another example is when Simba discusses a way to distract hyenas, then he decides to use a unique way in which he tells Timon to dress like a hula dancer and Pumba as a roasted pork in order to distract the hyenas.

Inclusive is invitation and appreciation which done by a leader in the form of words or action for someone else's participation (Nembhard \& Edmondson, 2006). Simba shows this character 2 times in the movie. He starts to develop this character since the middle part of the movie until the end part. Simba shows inclusive character when Timon and his friends insisted to join Simba in saving the pride rock. Simba's inclusive character is shown when he smiles to Timon as his appreciation to Timon's good intention in joining Simba's group. Then, in the end part Simba holds Rafiki as his gratefulness to Rafiki in helping his mission of ending Scar's evil domination.

\section{Conclusion}

This study finds that there are 20 values of characters education based on Ministry of Education and Culture theory. Those are religious, sincere, nature loving, peace loving, nationalistic, tolerant, patriotic, discipline, autonomous, creative, hardworking, resilient, cooperative, solidary, inclusive, appreciative, integrity, responsible, honest, loyal. From those values there are 9 values which are appear since the beginning of the movie such as; religious, tolerant, discipline, autonomous, hardworking, cooperative, solidary, responsible, and honest character. Then, there are 11 character which are started to appear in the middle of the movie, such as; sincere, nature loving, peace loving, patriotic, creative, resilient, appreciative, integrity, loyal, inclusive, and nationalistic. From the result of this study, it is proved that there are values of character education which stated by Ministry of Education and Culture on Simba as the main character in the Lion King (1994) movie. This research is a new finding on how character values are found in a movie character especially in Simba. The new findings of this research can deepen and sharpen the previous research on Simba and can be developed to further research.

\section{References}

Alfaiz, F. (2016). Pembelajaran Afektif Merupakan Salah Satu Strategi Dalam Pembentukan Karakter Peserta Didik (Sebuah Tinjauan dari Perspektif Psikologi; Social Cognitive Theory). Jurnal Pelangi, 7(1). https://doi.org/10.22202/jp.v7i1.152

Azizah, A. T. N. (2013). Perbandingan Nilai-nilai Patriotisme dalam Film (Analisis Isi Perbandingan NilaiNilai Patriotisme dalam Film Sang Pencerah (2010) dan Film Sang Kiai ( 2013 ) ) Andita Trias Nur 
Azizah Pawito Program Studi Ilmu Komunikasi Fakultas Ilmu Sosial dan Ilmu P. Publikasi, (2010), 1-20. https://digilib.uns.ac.id/dokumen/detail/45316/Perbandingan-Nilai-Nilai-Patriotismedalam-Film-Analisis-Isi-Perbandingan-Nilai-Nilai-Patriotisme-dalam-Film-Sang-Pencerah2010dan-Film-Sang-Kiai-2013.

Bordwell, D., \& Thompson, K. (2010). Film Art An Introduction. New York: McGraw-Hill.

Cheung, Chau-kiu. Lee, Tak-yan. (2010). Improving social competence through character education. Evaluation dan Program Planning. 33 (3) pp 255-263. https://doi.org/10.1016/j.evalprogplan.2009.08.006

Derlina, Tri Harsono. Sabani. (2014).Pengembangan Model Pembelajaran Fisika Umum Berbasis Pendidikan Karakter Di Program Studi Pendidikan Fisika FMIPA Unimed. Jurnal Pendidikan Fisika. 3(1) pp 16-23. https://doi.org/10.22611/jpf.v3i1.3271

Devi, N. K. T. W. P. (2018). Character Education Values in The Characterization of Brad Cohen in Front of The Class. Universitas Pendidikan Ganesha.

Fatah, Rois Abdul. (2018). Pendidikan Karakter Dalam Novel Mahamimpi Anak Negeri Tinjauan Psikologi Sastra. Jurnal Gramatika: Jurnal Penelitian Pendidikan Bahasa dan Sastra Indonesia. 4(1):12-23. https://doi.org/10.22202/jg.2018.v4i1.2412

Hartini, S. (2017). Sri Hartini, Pendidikan Karakter Disiplin. Journal Basic Of Education, 2(2), 38-59. DOI : 10.24269/ajbe.v2i1.882

Hinson, H. (1994). The Lion King review. The Washington Post. Retrieved from http://www.washingtonpost.com/wp-srv/style/longterm/review96/lionkinghin.htm

Hornby, A. S. (2005). Oxford Advanced Learner's Dictionary. (S. Wehmeier, Ed.) (7th ed.). Oxford University Press.

Humaira, M. (2018). An Analysis OF Moral Values in Zootopia Movie. Ar-Raniry State Islamic University.

Kemendikbud. (2017). Konsep dan Pedoman Penguatan Pendidikan Karakter. Pusat Analisis dan Sinkronosasi Kebijakan Sekretariat Jenderal Kementrian Pendidikan dan Kebudayaan.

Kim, Sunjin. Choe, Insoo. Kaufman, James C. (2019). The development and evaluation of the effect of creative problem-solving program on young children's creativity and character. Thinking Skills and Creativity. Vol 33. https://doi.org/10.1016/j.tsc.2019.100590

Lin, Tao. Morishima, Shigeo. Maejima, Akinobu. Tang, Ningjiu. (2010). The effects of virtual characters on audiences' movie experience. Interacting with Computers. 22(3) pp 218-229. https://doi.org/10.1016/j.intcom.2009.11.010

Miles, M. B., \& A. Huberman, M. (1994). Matthew B. Miles, Michael Huberman - Qualitative Data Analysis_ An expanded Sourcebook 2nd Edition http://www.theculturelab.umd.edu/uploads/1/4/2/2/14225661/miles-huberman-saldanadesigning-matrix-and-network-displays.pdf

Muzaki, F. I. (2016). Character Education in the Last Song: A Conceptual Review. Journal of Education and Human Development, 5(2), 149-154. https://doi.org/10.15640/jehd.v5n2a18

Nasional, K. P. (2010). Pengembangan Pendidikan Budaya dan Kaakter Bangsa. Bangsa. Jakarta: Badan Penelitian dan Pengembangan Pusat Kurikulum.

Nembhard, I. M., \& Edmondson, A. C. (2006). Making it safe: The effects of leader inclusiveness and professional status on psychological safety and improvement efforts in health care teams. Journal of Organizational Behavior, 27(7), 941-966. https://doi.org/10.1002/job.413

Nurpratiriningsih, L. (2011). Pelaksanaan Program Wajib Belajar 9 Tahun di Kecamatan Kedungbanteng Kabupaten Tegal. https://lib.unnes.ac.id/11158/

Payani, N. L. P. D. (2018). Character Education on The Main Character of Zootopia. University Pendidikan Ganesha. http://dx.doi.org/10.23887/jpbi.v5i2.14955

Pramadiansyah, Y. (2014). Pengaruh Televisi Terhadap Pembentukan Perilaku Kekerasan. Universitas Indonesia. 
Prasetyo, Danang. Marzuki, Marzuki. 2016. Pembinaan Karakter Melalui Keteladanan Guru Pendidikan Kewarganegaraan Di Sekolah Islam Al Azhar Yogyakarta. Jurnal Pendidikan Karakter. 6(2). https://doi.org/10.21831/jpk.v6i2.12052

Qurrata A'yunin, Ninuk Lustyantie, Shafruddin Tadjuddin. (2019). Nilai Pendidikan Karakter dalam Buku Autobiografi Happy Little Soul karya Retno Hening Palupi. Dialektika: Jurnal Bahasa, Sastra, dan $\begin{array}{lllll}\text { Pendidikan Bahasa dan } & \text { 179-195 }\end{array}$ https://doi.org/10.15408/dialektika.v5i2.7584

Rasyid, H. (2015). Membangun generasi melalui pendidikan sebagai investasi masa depan. Jurnal Pendidikan Anak, 4, 565-581. https://doi.org/10.21831/jpa.v4i1.12345

Reiner, H. (2009). Simba's Leadership - A Socio-Symbolic Content Analysis and its Empirical Examination among Children and Students. Journal of Social Sciences, 20(2), 121-128. https://doi.org/10.1080/09718923.2009.11892730

Riana, D. (2015). An Analysis of Moral Values Found in "Frozen" Movie. State Islamic College of Ponorogo.

Rukiyati. (2017). Pendidikan Moral Di Sekolah. Jurnal Humanika, (1), 70-80. https://journal.uny.ac.id/index.php/humanika/article/viewFile/23119/11628

Saputra, Nofrans Eka. Ekawati, Yun Nina. Islamiah, Rahmadhani. (2020). Skala Karakter Religius Siswa SMA Implementasi Nilai Utama Karakter Kemendikbud. Jurnal Pengukuran Psikologi dan Pendidikan Indonesia. 9(1):57-76. https://doi.org/10.15408/jp3i.v9i1.14782

The Walt Disney, C. (2004). 2004. Annual Report, (Chapter 1). https://doi.org/10.1016/B978-0-12088441-4.50000-9

Valor, Carmen. Antonetti, Paolo. Merino, Amparo. (2020). The relationship between moral competences and sustainable consumption among higher education students. Journal of Cleaner Production. Vol 248. https://doi.org/10.1016/j.jclepro.2019.119161

Ward, A. R. (1996). The Lion King's Mythic Narrative.pdf. Journal of Popular Film \& Television, 23(4), 171178. https://doi.org/10.1080/01956051.1996.9943703

Wilson, E. (1976). The Theater Experience (4th ed.). United Stated of America.

Zhou, Shou. Shapiro, Michael A. Wansink, Brian. (2017). The audience eats more if a movie character keeps eating: An unconscious mechanism for media influence on eating behaviors. Appetite. $108 \mathrm{pp}$ 407-415.https://doi.org/10.1016/j.appet.2016.10.028 